\title{
Editorial
}

\section{'At long last'}

Fred C. de Hosson, Caron \& Stevens/Baker \& McKenzie, Amsterdam

For many it still came as a surprise. Only recently, an otherwise very well-informed columnist wrote: 'I suggest that 1994 is more likely to see a US victory in the World Cup than it is to see meaningful progress toward the harmonization of direct taxes in the European Community.' (Mike McIntyre, Tax Notes International, February 1990). Since then, the excellent football played by the United States during the World Cup in June, especially against Italy, must have made him think again.

The credit for the adoption of the two directives (Merger \& Acquisition and ParentSubsidiary) and Convention (Arbitration) on 11 June is due to the politicians, it must be said. If it had been up to the civil servants of the various Member States, the chance would have been by no means slim that the adoption of the two directives and Convention would still be a long way off at the time of the World Cup matches in the United States in 1994. The German finance minister's preparedness to come to an agreement with his Dutch colleague in the lobbies of the last ECO-FIN Council meeting regarding the term within which Germany should abolish its withholding tax on dividends (mid-1996), led to the crumbling of the last obstacle for the integral adoption of the two directives and Convention. The speed with which the directives and Convention were adopted even led to some confusion as to the question which text has actually been adopted, and the texts themselves cannot quite dispel the impression that they had not been looked at for some time.

Now, the question is what will be the consequence of adopting the parcel of directives and Convention.

I think that now this important first step has been taken, of which many thought it likely to never happen at all or maybe in the distant future, an important psychological barrier has disappeared. Generally, it is assumed that the directive which abolishes the levy of withholding tax on interest and royalties will be adopted in the near future. More time will be involved with regard to the directive concerning the inter-community compensation of losses, which is technically very complicated, but there is also in this matter a political desire for progress.

The developments will not be without consequences for the relationships of third countries with EC Member States. As a result of the introduction of 0 per cent rates for parentsubsidiary dividends relations, countries which are interested in new ties with the EC, such as the EFTA Member States, are considerably more prepared to introduce a 0 per cent rate in the bilateral tax treaties with EC Member States as well.

It is likely that the emergence of the Community as a more coherent entity now in the direct tax area as well, will also change the relationship with the United States. There is already some pressure to treat the Member States of the EC as a single country for purposes of the Subpart legislation. Likewise in the treaty area, there are indications that the United States is more prepared to take into account the existence of the Community, most notably by accepting ownership by EC residents as relevant when drafting the ownership test under the Limitation on Benefits article. The memorandum of Understanding forming part of the new (not yet ratified) US-Germany tax treaty already gave a clear indication of this development. More recent treaty negotiations show that the US Treasury is more and more prepared to regard the Community as a whole, in this respect, too (which does not mean, however, that Congress will agree with the results).

It goes without saying that Intertax cannot ignore these developments. The next issue will therefore be dedicated entirely to the birth of the federal direct tax legislation in the Community. 